\title{
OPTIMAL CHOICE OF ANTIRETROVIRAL THERAPY REGIMEN INCLUDING PHOSPHAZIDE
}

\author{
Elvira Ivanova $a^{10}$ (D), Natalya Vorobyova ${ }^{2}$, \\ Michail Okishev ${ }^{2}$, Vera Nikovenko², Olga Sumlivaya ${ }^{2}$ \\ 1 Perm Regional Center for AIDS and Infectious Diseases, Perm \\ ${ }^{2}$ E. A. Vagner Perm State Medical University, Perm \\ $\triangle$ aids ivanova@mail.ru
}

ABSTRACT - A clinical and laboratory study on selection, prescription and use of optimal antiretroviral therapy regimens for HIV patients was conducted. It was identified, that phosphazide has significant therapeutic efficacy and safety among nucleoside analog reverse-transcriptase inhibitors.

KEYWORDS — safety, phosphazide, HIV infection, therapy.

\section{NTRODUCTION}

It is known that HIV infection is one of the most complex biomedical health problems in the world. The disease causes negative consequences, signs of an emergency and long-term problems, including death $[1,2]$. In Russia, there is an annual increase in morbidity, social significance and epidemiological danger, which dictates the need of new approaches to HIV/AIDS retroactions including safe and effective drug usage. According to Russian guidelines, antiretroviral therapy (ART) is carried out using the combination of at least three drugs $[3,4]$.

To achieve the long-term therapeutic effect of ART, it is necessary to select treatment regimens with effective and safe drugs based on the objective principles of rational drug use.

Using the expert system AntiHIV-1 which includes the elements of the Rational Unified Process (RUP) software methodology, optimal and safe treatment regimen, including a NRTI class drug — phosphazide, were selected.

\section{METHODOLOGY, MATERIALS AND RESEARCH METHODS}

The medical expert system AntiHIV-1 was created in 2017 on the basis of Perm State Center for the Prevention and Control of AIDS and Infectious Diseases by Federal State Budgetary Educational Institution of Higher Education Perm State Pharmaceutical Academy of the Ministry of Health of the Russian Federation with contribution from Perm National Research Polytechnic University.
Taking into account the criteria of effectiveness and safety, the safest drug of the class of nucleoside reverse transcriptase inhibitors (NRTIs) in ART regimens was determined.

\section{MAIN CONTENT OF THE STUDY AND ANALYSIS OF THE RESULTS}

In the automatic information system AntiHIV-1 for analysis of the choice and purpose of ART, 33 used antiretroviral drugs from six classes registered in the state register of medicines were included. 25 of them were monocomponent drugs and 8 were complex (two- and three-component), they were included into the pharmacotherapeutic group J05A Direct-acting antiviral drugs according to the Anatomical Therapeutic Chemical Classification (ATC) classification [5].

599 medical records of patients receiving ART on an outpatient basis were analyzed, which made it possible to identify side effects and draw conclusions about the toxicity of the drugs used.

ART regimen with phosphazide were the safest one. Phosphazide is the first Russian NRTI class drug that was synthesized in the laboratory of the Institute of Molecular Biology. V.A. Engelhardt RAS [6] (Fig. 1)

Fig. 1. Phosphazide chemical formula<smiles>Cc1cn(C2CC([N])C(COP(=O)([O-])O[Na])O2)c(=O)[nH]c1=O</smiles>

High anti-HIV activity of phosphazide against HIV-1 reproduction in cultures of H9, MOLT and MT-4 lymphoblastoid cells was established (Galegov, 1988) as well as low toxic effects on tissues and organs $[7,8,9,10]$.

We had also studied its safety and low toxicity in the schemes of perinatal chemoprophylaxis of motherto-child HIV transmission, treatment of infection and prevention of parenteral infection of medical workers in the course of their duties earlier. [11-14]. 
As a result, $\mathrm{ART}$ regimens with the least number of undesirable side reactions (ADR) from organs and systems were identified - this is a combination of 2 NRTIs $+\mathrm{AI}$ - tenofovir + phosphazide + dolutegravir $(73$ (11.8\%) of 617 ADR), while the combination of abacavir + phosphazide + dolutegravir potentially causes only 8 (1.3\%) ADR, which are the same for all three drugs.

Among the alternative ART regimens, phosphazide + emtricitabine + fosamprenavir (52 (8.4\%) of 617 ADR), phosphazide + emtricitabine + atazanavir, and phosphazide + emtricitabine + fosamprenavir / ritonavir with five (0.8\%) ADR should be marked.

The analysis of the clinical laboratory diagnostics results, changing under the influence of antiretroviral therapy drugs, revealed ART regimens, the use of which causes the least effect on the change in laboratory parameters. These are the following drug combinations recommended in the Russian Federation: phosphazide + emtricitabine + fosamprenavir, phosphazide + emtricitabine + saquinavir / ritonavir, phosphazide + lamivudine + fosamprenavir, phosphazide + lamivudine + saquinavir / ritonavir.

Among monocomponent ART drugs, phosphazide is characterized by the least number of potential manifestations of ADR - $10 \mathrm{ADR}(1.6 \%)$.

There should be noted such ART drug regimens that do not influence the indicators of clinico-laboratorial diagnostics ( 0 indicators of CLD $(0.0 \%)$ out of 42) for the treatment of HIV infection: phosphazide + emtricitabine + atazanavir and phosphazide + lamivudine + fosamprenavir [15-17].

\section{CONCLUSION}

As a result of the use of the AIS AntiHIV-1, the optimal ART regimens which have the least amount of side effects were determined. All schemes include a representative of NRTI class - phosphazide, which is registered and manufactured in Russia.

\section{REFERENCES}

1. Chernyavskaya O. A., Ioanidi E. A., Makarova I. V. AND OTHERS. HIV treatment. Medicinal Bulletin. 2010; 6 (38): 3-9.

2. WHO [Electronic source] - http://www.who.int/ru. - [Date of reference 15.02.2016].

3. PokrovskiY V.V., YURIN O.G., Kravchenko A.V., Belyaeva V.V., Kanestri V.G., Afonina L.Yu., Ermak T.N., Buravtsova E.V., ShakHGiL'dyan V.I., KozYrina N.V., NarSIYa R.S., Zimina V.N., PoKrovskaya A.V., Efremova O.S. Natsional'nye rekomendatsii po dispansernomu nablyudeniyu i lecheniyu bol'nykh VICh-infektsiey (klinicheskiy protokol) [National recommendations for dispensary observation and treatment of patients with HIV infection (Clinical protocol)] // Epidemiologiya i infektsionnye bolezni. Aktual'nye voprosy - Epidemiology and Infectious Diseases. Current Items. 2015; 6: 120 (in Russian).
4. Svodnoe rukovodstvo po ispol'zovaniyu antiretrovirusnykh preparatov dlya lecheniya i profilaktiki VICh-infektsii. Kratkiy obzor osnovnykh osobennostey i rekomendatsiy [Consolidated guidance on the use of antiretroviral drugs for the treatment and prevention of HIV infection. A brief overview of the main features and recommendations] // VOZ - WHO. 2013: 16 (in Russian).

5. Gosudarstvenniy reestr lekarstvennych sredstv. Access mode: http://grls.rosminzdrav.ru/default.aspx.

6. Yurin O., Kraevskiy A., Afonina L. And others (2001). Phosphasid - new and Russian ARV - drug, Epidemiology and Infectious Diseases, №1, p. 43-45.

7. GALEGOV G. (2004).Nikavir (phosphaside) - ARV - drug: anti HIV-activity, toxicology, pharmacokinetics and some perspectives for using, Antibiotics and chemotherapy, part 49, №7, p. 3-8.

8. Skoblov Y., Karpenko I., Shirokova E. eT AL. (2004). Intracellular metabolism and pharmacokinetics of 5'-hydrogenphosphonate of 3'-azido-2',3'-dideoxythymidine, Antiviral Research, Vol. 63(2), p. 107-113.

9. Brinkman K., Hofstede H., Burger D. M., Smeitink J. A., Koopmans P.P. Adverse effects of reverse transcriptase inhibitors: mitochondrial toxicity as common pathway. AIDS. 1998;12:1735-44.

10. LANDER B. A., Kemp S. D. Multiple mutations in HIV-1 reverse transcriptase confer high-level resistance to zidovudine (AZT). Science.1989;246:1155-1158.

11. Ivanova E. S., Shmagel N. G., Vorobyova N. N., Chafizov K. M. Effectivity and safety of neovir in the schemes of perinatal chemoprophylaxis of motherto-child HIV transmission. Thesis of the III HIV/ AIDS Conference in South Europe and Central Asia. Moscow; 2009; 1: 59-60 (Russia).

12. Ivanova E. S., Shmagel N.G., Vorobyova N.N. Nikavir in Chemoprevention Regimens of Vertical HIV transmission. Understanding HIV/AIDS Management and care. Pandemic Appproaches in the $21^{\text {st }}$ century. Ed. FysonHananiaKasenga, Publ.: InTech, DOI: $10.5772 / 24428$.

13. Ivanova E. S., Vorobyova N. N., SADYkova D. K. Complex chemotherapy of HIV - positive pregnant women. 2014; 4(12): 28-32.

14. Ivanova E. S., Vorobyova N. N., Kresnopyorova N. N., OKISHEv M. A. Comparative analysis of different drug regimens for post-contact HIV - prevention in medical workers. "Clinical Medicine" 2016; 4(94): 295-299.

15. Rostova N. B., Gulina N. A. Rational therapy criteria on the HIV-infection example. Questions of Virology. 2018; 63 (1): 41-47.

16. Gulina N. A., Rostova N. B. Side drug reactions as the criteria of drug safety. Medical Almanach. 2017; 3(48):186-192.

17. Gulina N.A., Ivanova E.S., Sibiryakov A.V., Mechanoshona N.V., Rostova N.B., FaizrachMANOV R.A. Cluster analysis in developing and choosing the drug regimen in HIV - positive patients. Bulliten Sibirskoy Medicini. 2017; 16 (3): 52-60. 